\title{
Changes in the Growth Hormone-IGF-I Axis in Non-obese Diabetic Mice
}

\author{
DANIEL LANDAU ${ }^{\mathrm{a}, *}$, YAEL SEGEV $^{\mathrm{a}}$, RINA ESHET $^{\mathrm{b}}$, ALLAN FLYVBJERG $^{\mathrm{c}}$ and MOSHE PHILLIP ${ }^{\mathrm{a}, \mathrm{b}}$ \\ ${ }^{a}$ Molecular Endocrinology Laboratory, Soroka Medical Center, Ben Gurion University of the Negev, Beer Sheva; \\ ${ }^{\mathrm{b}}$ Felsenstein Medical Research Center, Institute for Endocrinology and Diabetes, Schneider Children's Medical Center; \\ ${ }^{\mathrm{c}}$ Institute of Experimental Clinical Research, Aarhus Kommunehospital, Aarhus C., Denmark
}

(Received 25 July 1999; In final form 2 August 1999)

We investigated the changes in GH-IGF-I axis in non-obese diabetic (NOD)-mice, a model of insulindependent diabetes mellitus. Diabetic female NOD mice and their age- and sex-matched controls were sacrificed at 4, 14, 21 and 30 days $(30 d D M)$ after the onset of glycosuria. Serum GH levels increased and serum IGF-I levels decreased in the $30 \mathrm{~d}$ DM group $(182 \pm 32 \%$ and $45 \pm 24 \%$ of age-matched controls respectively, $p<0.05)$. Another group $(30 d D M+I)$ was given SC insulin, and its serum IGF-I levels remained decreased. Liver $G H$ receptor (GHR) and GH binding protein (GHBP) mRNA levels, as well as liver membrane $\mathrm{GH}$ binding assays were deeply decreased in the $30 \mathrm{~d}$ DM group in comparison to controls. GHR message and binding capacity remained decreased in the $30 \mathrm{~d} D M+I$ group. Renal GHR mRNA was decreased at 21d DM but not at 14d DM, whereas GHBP mRNA remained unchanged throughout the experiment. In conclusion, increased serum GH levels are documented in NOD diabetic mice, similarly to the changes described in humans. The decrease in GHR levels and decreased serum IGF-I in spite of increased circulating GH suggest a state of $\mathrm{GH}$ resistance.
Keywords: Non-obese diabetic mouse, growth hormone, growth hormone receptor, insulin-like growth factor I

\section{INTRODUCTION}

IDDM is accompanied by long-term complications, including nephropathy, retinopathy, neuropathy and advanced atherosclerosis (Deckert et al., 1978). The appearance of these complications, mainly nephropathy, increases the relative mortality of IDDM patients by 100 times that of the background population (Borch-Johnsen et al., 1985). Growth hormone (GH) and insulinlike growth factors (IGFs) may participate in the development of diabetic kidney disease (Flyvbjerg et al., 1992, 1989; Bach and Jerums, 1990; Phillip et al., 1994; Werner et al., 1990), as well as other diabetic complications (Holly et al., 1988; Houssay, 1936).

*Corresponding author. Department of Pediatrics, Soroka Medical Center. P. O. Box 151, Beer Sheva 84101, Israel. Tel.: 972-76403219, Fax: 972-7-6400528, e-mail: ldaniel@bgumail.bgu.ac.il 
The classical endocrine effect of pituitarysecreted GH is the induction of liver IGF-I production and secretion. This effect is mediated via activation of the specific GH receptor (GHR), which is extensively distributed in many tissues (Chin et al., 1992). Its binding to $\mathrm{GH}$ activates a signal transduction pathway (Cunningham et al., 1991), which leads to increased transcription of several early response genes (Gronowski and Rotwein, 1994). Therefore it is possible that GH exerts effects on target tissues which are independent of IGF-I. In addition, diabetic children and adolescents may not grow well (Murata et al., 1994; Phillips and Orawski, 1977). This growth retardation may be due to $\mathrm{GH}$ resistance (English et al., 1993).

Experimental diabetes in rats using streptozotocin (STZ) is characterized by suppressed circulating levels of GH (Tannenbaum, 1981). This is contrary to what has been described in humans (Blankestijn et al., 1993; Press et al., 1984; Hayford et al., 1980). In addition, typical diabetic glomerulosclerosis associated with increasing azotemia does not develop, even in longterm follow-up models. STZ may also induce tumoral growth in the kidney, and $\beta$-cell regeneration may appear (Horton et al., 1997; Chieco et al., 1993). In contrast, the non-obese diabetic (NOD)-mouse model may resemble human diabetic nephropathy more closely (Velasquez et al., 1990). The NOD-mice develop hypoinsulinemia secondary to autoimmune destruction of pancreatic $\beta$-cells at an age of between 100 and 200 days (Tochino, 1984), in association with insulitis and autoantibody production (Wicker et al., 1986). As in humans, NOD mice develop proteinuria and significant glomerular lesions, including a prompt increase in glomerular surface area and an increase in mesangial sclerosis (Doi et al., 1990).

No data are available on serum GH levels in NOD mice and their influence on liver IGF-I secretion. In the present study we evaluated the changes in serum GH and IGF-I, and analyzed the expression and activity of liver and kidney GHR and GHBP in NOD mice, up to four weeks after the appearance of diabetes.

\section{MATERIALS AND METHODS}

\section{Animals}

Twelve-week-old female NOD/Alt mice were purchased from Jackson Laboratories (Bar Harbor, ME, USA). Animal breeding complied with the NIH Guide for the Care and Use of Laboratory Animals. The cumulative incidence of overt diabetes in these animals is over $50 \%$ in females by 100 days. Animals were housed in standard laboratory cages and fed ad libitum normal mouse chow. Animals had free access to unlimited supplies of tap water. The appearance and persistence of glycosuria determined the onset of diabetes. This was checked weekly in all animals using chemstrips (Ketostix, BayerAmes, UK). When the urine glucose test was positive, tail capillary blood samples were checked with Glucometer Elite (Bayer Diagnostics, Puteaux Cedex, France). The normal range (99\% confidence level) of blood glucose levels for NOD mice is from 3.0 to $9.9 \mathrm{mmol} / \mathrm{L}$. Diabetes was diagnosed when blood glucose levels were above the normal range on two consecutive days. The day that glycosuria was first noted was considered as day 1 of diabetes. Diabetic mice were sacrificed 4 (group $4 d D M$ ), 14 (14d $D M), 21$ (21d DM) and 30 (30d DM) days after the onset of diabetes. Normoglycemic (as determined by normal blood glucose levels at the day of sacrifice) age-matched female NOD mice were used as controls (group C). Another group of diabetic NOD mice was treated with SC injections of Ultralente human insulin (Novo Nordisk, Denmark) on an every other day basis from the beginning of glycosuria. Insulin dosage was gradually increased to 4 units per injection, which only kept serum glucose levels below $25 \mathrm{mmol} / \mathrm{L}$ 
( $450 \mathrm{mg} / \mathrm{dl}$ ) and animals non-ketotic. This group was sacrificed after 30 days of diabetes (group 30d $D M+I$ ). Mice were sacrificed by decapitation. Trunk blood was collected and serum was separated and frozen in $-20^{\circ} \mathrm{C}$ to measure later GH and IGF-I levels. Liver and kidney tissue were removed carefully and immediately frozen in liquid nitrogen and then transferred to $-70^{\circ} \mathrm{C}$.

\section{Determination of Serum IGF-I}

Serum IGF-I was measured after extraction with acid-methanol (30 $\mu \mathrm{l}$ serum and $750 \mu \mathrm{l}$ acid-methanol). The mixture was incubated for 2 hours at room temperature, centrifuged and $25 \mu \mathrm{l}$ of the supernatant was diluted 1:200 before analysis. Serum IGF-I was measured by radioimmunoassay (RIA) using a polyclonal rabbit antibody (Nichols Institute Diagnostics, San Capistrano, Calif., USA) and recombinant human IGF-I as standard (Amersham International, Amersham, Bucks, UK). Mono-iodinated IGF-I ( ${ }^{125} \mathrm{I}-\left(\mathrm{tyr}^{31}\right)$-IGF-I) was obtained from Novo-Nordisk A/S, Bagsvaerd, Denmark. When exposing the serum extract to Western ligand blot (WLB), no IGFBPs could be identified. Furthermore, semilog linearity of biosynthetic IGF-I and serum extracts was seen, indicating antigen similarity and that no IGFBPs interfered in the RIA. Intra- and interassay variability was below 5 and $10 \%$, respectively.

\section{Serum GH Determination}

Serum GH was measured by radioimmunoassay (RIA) using specific polyclonal rabbit anti-rat$\mathrm{GH}$ (rGH) antibody and $\mathrm{rGH}$ as standard. Semilog linearity of mouse serum and rGH (in the standard) was found at multiple dilutions, indicating antigen similarity between mouse $\mathrm{GH}$ and $\mathrm{rGH}$. The ingredients including ${ }^{125} \mathrm{I}-\mathrm{rGH}$ were obtained from Amersham (Amersham International, Bucks, UK). Intra- and interassay coefficients of variation were less than $5 \%$ and $10 \%$. However, in the present study all samples were run in one assay.

\section{mRNA Analysis}

Frozen tissues in $4 \mathrm{M}$ guanidinium isothiocyanate were loaded on cesium chloride and total RNA was isolated following the methods as described elsewhere (Phillip et al., 1994). The precipitated RNA was resuspended in sterile $\mathrm{H}_{2} \mathrm{O}$ and quantitated by absorbency at $260 \mathrm{~nm}$. The integrity equivalent loading of total RNA was assessed by visual inspection of the ethidium bromide-stained $28 \mathrm{~S}$ and 18S RNA bands after electrophoresis through $1.25 \% / 2.2 \mathrm{M}$ formaldehyde gels. Liver and kidney GHR and GHBP mRNA levels were determined using Northern blot analysis. Twenty $\mu \mathrm{g}$ of total RNA were electrophoresed on $1.3 \%$ agarose/2.2M formaldehyde gel in 3-MOPS buffer. The RNA was then transferred onto MagnaGraph (MSI, Westboro, MA, USA) nylon membrane and was crosslinked to the membrane with a UV crosslinker (Hoefer Scientific Instr., San Francisco, CA, USA). A $4.4 \mathrm{~kb}$ transcript encoding the GHR and a $1.2 \mathrm{~kb}$ transcript encoding the GHBP were detected using a $964 \mathrm{bp}$ fragment of the GHR cDNA, comprising the extracellular domain, the putative transmembrane region, and the short section of the intracellular domain (a gift of L. Mathews). This construct was linearized using BamH1 and radiolabelled with $\alpha{ }^{32}$ PdCTP (3000 $\mathrm{Ci} / \mathrm{mmol}$; Amersham) by a random primed DNA labelling kit (Boerhinger Manheim, $\mathrm{GmbH}$, Germany). RNA hybridization was performed in a hybridization oven (Micro-4 Hybaid Ltd, UK) at $65^{\circ} \mathrm{C}$ for 20 hours in hybridization solution $\left(0.2 \mathrm{mM} \mathrm{Na} \mathrm{HPO}_{4}, \mathrm{pH}\right.$ $7.2 ; 7 \%$ vol./vol. SDS; $1 \% \mathrm{wt} /$ vol. BSA; and $1 \mathrm{mM}$ EDTA). The washings were done in $0.4 \mathrm{X}$ SSC and $0.1 \%$ SDS at $65^{\circ} \mathrm{C}$. Gels were exposed to Kodak X-Omat AR film (Eastern Kodak, Rochester, NY, USA) at $-70^{\circ} \mathrm{C}$ with 2 intensifying 
screens. The autoradiograms were quantitated using a phosphorimager (Imagequant, Molecular Dynamics, Sunnyvale, CA, USA).

\section{Receptor Preparation}

Receptor preparation was carried out as previously described (Tushina and Friesen, 1973). Liver was homogenized in $0.25 \%$ sucrose solution, centrifuged at $10,000 \mathrm{~g}$ for 10 minutes followed by further centrifugation of the supernatant at $100,000 \mathrm{~g}$ for 90 minutes, which yielded the microsomal pellet. The pellet was then resuspended in $25 \mathrm{mM}$ Tris- $\mathrm{HCl} / 10 \mathrm{mM} \mathrm{MgCl} 2$ buffer ( $\mathrm{pH}$ 7.4). The quantity of microsomal proteins was measured by the method of Lowry et al. (1951), using human serum albumin as a standard. The microsomal fraction was frozen and thawed 3 times and then kept frozen until used for the binding studies (Bergeron et al., 1978). The human somatotropin (hGH, 20 I.U./ $\mathrm{mg}$ protein) used for iodination and as standard was generously donated by Kabi Diagnostica, Stockholm, Sweden. Na ${ }^{125}$ I (NEZ-033A), carrier free, was purchased from NEN Life Science Products (Boston, USA). Iodination of hGH and binding assays were performed as previously described by us (Eshet et al., 1985). Iodinated preparations were used no more than 2 weeks after iodination. One hundred $\mu \mathrm{l}$ of labelled hGH $(25,000 \mathrm{cpm})$ were incubated with the liver microsomal pellet fraction and $100 \mu \mathrm{l}$ of various concentrations of unlabelled $\mathrm{hGH}$ in $25 \mathrm{mM}$ Tris- $\mathrm{HCl} / 10 \mathrm{mM} \mathrm{MgCl} 2$ buffer ( $\mathrm{pH}$ 7.4) containing $0.1 \%$ bovine serum albumin in a final volume of $0.5 \mathrm{ml}$. This was incubated at $4^{\circ} \mathrm{C}$ with constant shaking for 48 hours and the incubation was terminated by adding $2 \mathrm{ml}$ ice-cold $0.1 \%$ bovine serum albumin/Tris/Mg buffer as noted above. Receptor-bound and free radioactivity was separated by centrifugation at $2000 \mathrm{~g}$ for 30 minutes at $4^{\circ} \mathrm{C}$. Radioactivity was measured in an autogamma scintillation spectrometer. Parallel incubations were made in the presence of excess $(5 \mu \mathrm{g} / \mathrm{ml})$ unlabelled hormone.
Specific binding is the difference between radioactivity bound in the absence (TB, total binding) and the presence (NSB, non-specific binding) of excess unlabelled hormone and is expressed as a percentage of the total radioactivity in the incubation. The capacity and the dissociation constant of liver $\mathrm{GH}$ receptor were evaluated using the Scatchard plot analysis.

\section{Statistical Analysis}

Statistical differences between groups were determined by one-way ANOVA for non-repeated measures. Dunnett's test was used to find the source of significance in relation to controls. $P$ values equal or less than 0.05 were considered significant. Values are expressed as mean \pm SEM unless otherwise stated.

\section{RESULTS}

The mice used in this study ( $n=6$ in each group) became diabetic at a mean age of $104 \pm 15$ days. Control mice had a mean age of $119 \pm 6$ days when sacrificed ( $p=$ NS). Diabetic mice weight was lower than controls $(23 \pm 0.6$ and $18.3 \pm 0.8$ grams in the $4 \mathrm{~d} D M$ and $30 \mathrm{~d} D M$ groups respectively, vs. $25.3 \pm 0.7$ grams in control animals; $P<0.01)$. The weight of the $30 \mathrm{~d} D M+I$ group (diabetic animals treated with insulin) was also lower than controls $(85.6 \pm 2 \%$ of control, $P<0.01$ ) but higher than the $30 \mathrm{~d} \mathrm{DM}$ animals $(21.7 \pm 0.61$ vs. $18.3 \pm 0.82$ grams; $P<0.01)$ (Fig. 1a).

Serum IGF-I levels did not change during the first two weeks of diabetes, but a significant decrease was observed after 4 weeks in diabetic animals $(158 \pm 38$ vs. $351 \pm 15 \mathrm{ng} / \mathrm{ml}$ in controls, $p<0.05)$. Serum IGF-I remained low in the $30 \mathrm{~d} \mathrm{DM}+\mathrm{I}$ group $(40 \pm 9.9 \%$ of controls, $p<$ 0.05) (Fig. 1b). Serum GH levels were elevated in the $30 \mathrm{~d} D M$ group in comparison to controls $(51 \pm 9$ vs. $28 \pm 2 \mathrm{ng} / \mathrm{ml}$ respectively; $p<0.01$ ) (Fig. 1). In the $30 \mathrm{~d} D M+I$ such elevation was 

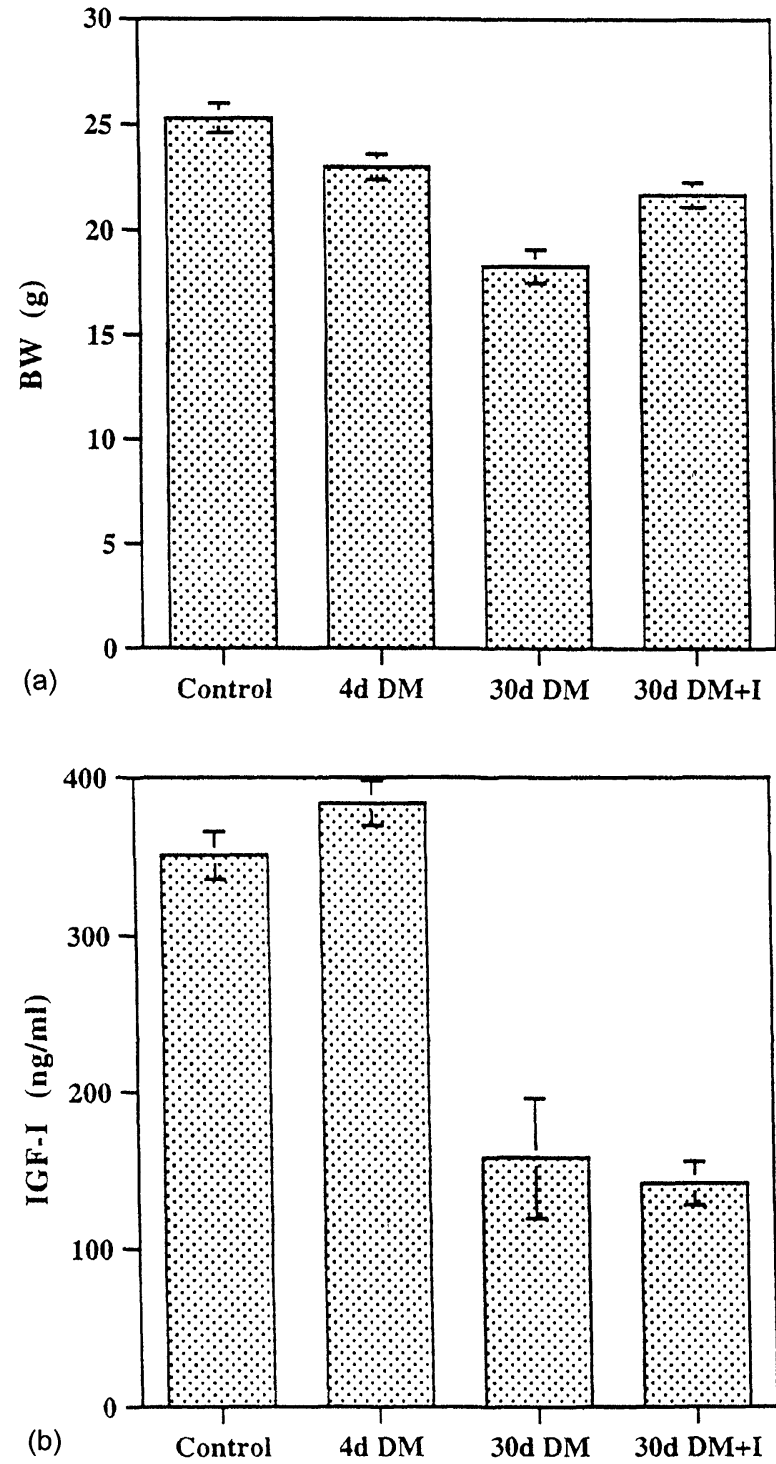

FIGURE 1 (a) Animal weight (BW, in grams), (b) serum IGF-I (in $\mathrm{ng} / \mathrm{ml}$ ) and (c) serum $\mathrm{GH}$ (in $\mathrm{ng} / \mathrm{ml}$ ) levels in NOD mice, in controls, 4 and 30 days diabetic (DM) mice. $30 \mathrm{DM}+\mathrm{I}$ : diabetic mice treated for 30 days with $4 \mathrm{IU}$ of ultralente insulin every other day. ${ }^{*} p<0.01$ vs. control.

not observed (Fig. 1c). Data on serum IGF-I levels have been previously described by us (Segev et al., 1997).

Steady state liver GHR mRNA levels were decreased in diabetic animals already at 4 days $(47 \pm 10 \%$ of control, $p=0.004)$ and persisted over one month of diabetes $(33 \pm 9 \%$ of

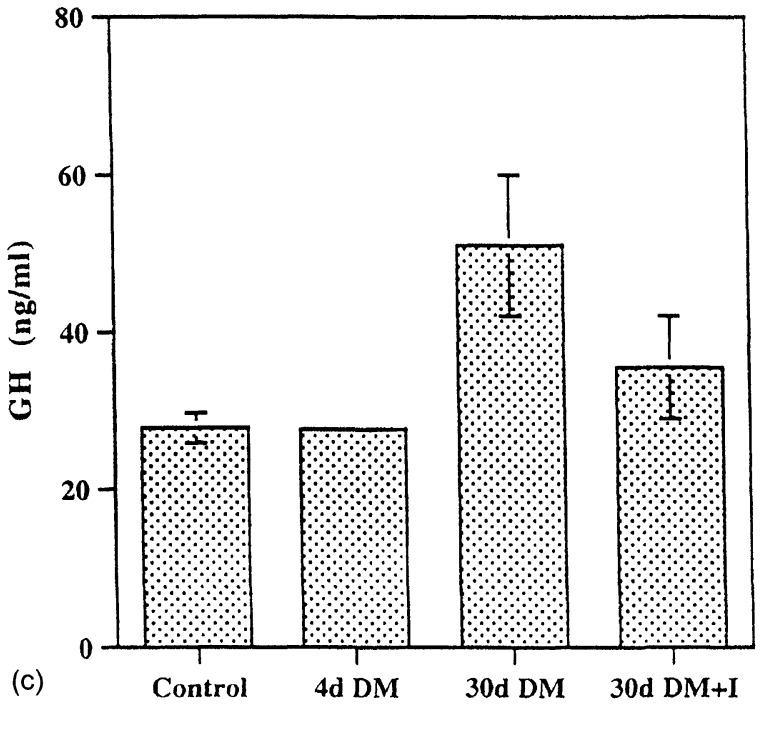

FIGURE 1 (Continued).

age-matched control, $p<0.001)$. The GHR message remained decreased in the $30 \mathrm{~d} D M+I$ group: mRNA levels remained as low as $20 \pm 2 \%$ of non-diabetic animals $(p<0.0001)$. Liver GHBP mRNA followed the same pattern as GHR mRNA, and its levels decreased to $67 \pm 4 \%$ and $30 \pm 4 \%$ of controls at 4 and 30 days of diabetes respectively $(p<0.001)$ (Fig. 2).

Renal GHR and GHBP mRNA levels showed complex changes in 2 and 3-week non-treated diabetic mice in comparison to controls (Fig. 3). GHBP mRNA remained unchanged in these two time points. Renal GHR mRNA was not significantly decreased at two weeks of DM ( $77 \pm 5.4 \%$ of age-matched controls; $p=\mathrm{NS}$ ), but the receptor message was significantly decreased at 3 weeks of DM $(30 \pm 10 \%$ of control; $p<0.01$ ).

GHR binding assays performed on liver membranes demonstrated a linear configuration. We found a decrease in the binding capacity of the receptor in diabetic mice after one month of diabetes in comparison to controls $(118 \pm 26$ vs. $475 \pm 63 \mathrm{fmol}$ receptor $/ \mu \mathrm{g}$ protein; $p<0.0001)$ whereas receptor affinity remained unchanged $(0.42 \pm 0.12$ vs. $0.28 \pm 0.03 \mathrm{nmol} / \mathrm{L}$; 

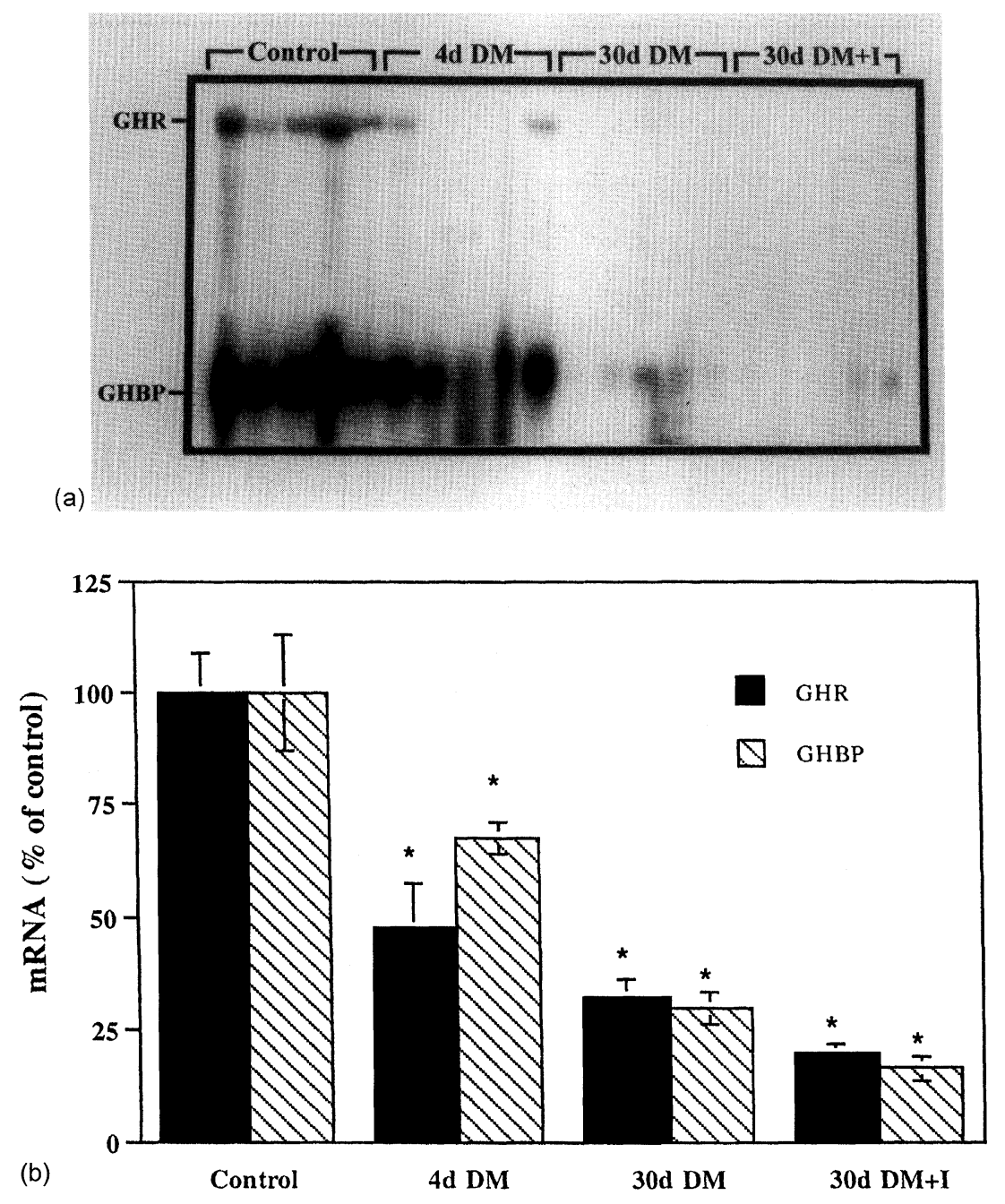

FIGURE 2 (a) Northern blot analysis of liver $(20 \mu \mathrm{g})$ total RNA of control, 4 days and 30 days diabetic (DM) NOD mice. $\mathrm{DM}+\mathrm{I}: 30$ day diabetic animals treated with $4 \mathrm{IU}$ of ultralente insulin. The $4.4 \mathrm{~kb}$ and $1.2 \mathrm{~kb}$ bands corresponding to the GHR and GHBP are shown on the left. Film was exposed for 96 hours at $-70^{\circ} \mathrm{C}$ with two intensifying screens. (b) Quantitation of liver GHR and GHBP levels from the autoradigraph shown in Figure 2a, using a phosphorimager. The data are expressed as the percentage of age-matched non-diabetic controls. $n=5$ rats in each group. ${ }^{*} p<0.05$ vs. control.

$p=\mathrm{NS})$. GHR binding capacity remained low and unchanged in the $30 \mathrm{~d}$ DM + I group (Fig. 4).

\section{DISCUSSION}

This study shows new evidence on the similarity of the NOD model to human IDDM: as in humans, increased circulating GH levels are found in these hyperglycemic mice, a change that is not modulated by insulin therapy. GH is usually secreted in a pulsatile fashion, and a single measurement of the serum GH may not properly reflect $\mathrm{GH}$ levels. However, in the control group $\mathrm{GH}$ has also been sampled in the same way. In addition, the decapitation procedure for blood sampling in our experiment has been shown to be a significant stimulus for GH secretion (Takahashi et al., 1971). Thus, the results presented by us reflect a true increase 


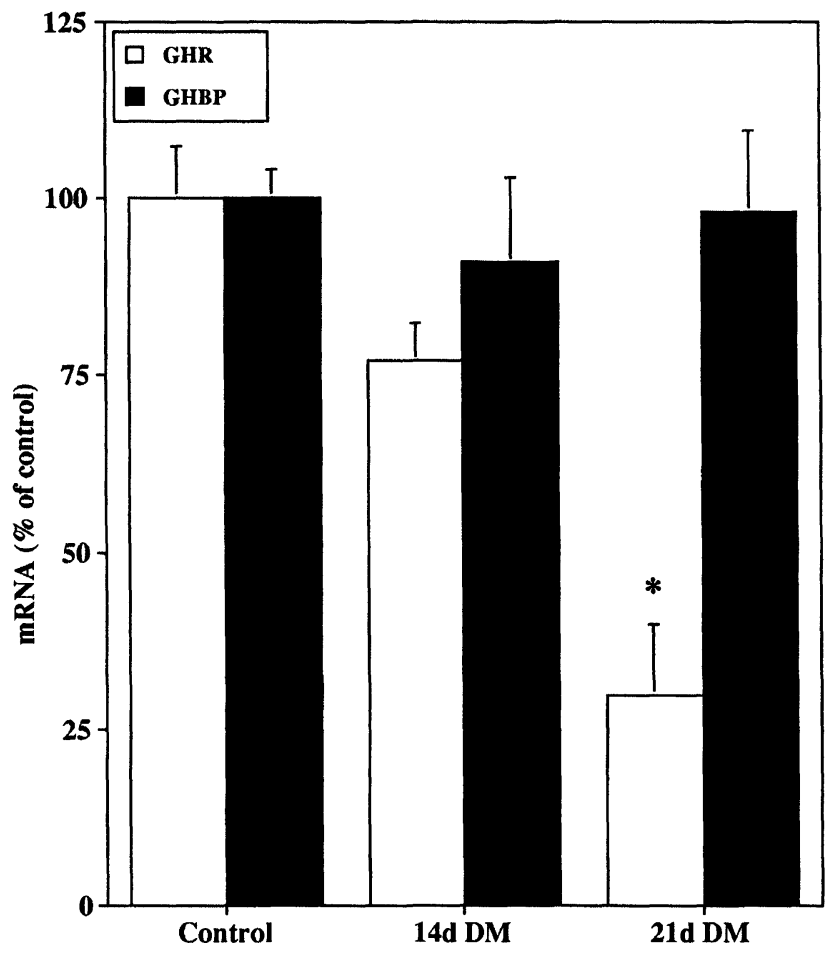

FIGURE 3 Northern blot analysis of kidney GHR and GHBP: $20 \mu \mathrm{g}$ total RNA of control, 14 and 21 day diabetic (DM) mice were analyzed. Renal GHR and GHBP levels were quantitated using a phosphorimager. Data presented summarize 3 series of experiments, repeated twice each. The data are expressed as the percentage of age-matched non-diabetic controls. ${ }^{*} p<0.001 v s$. control.

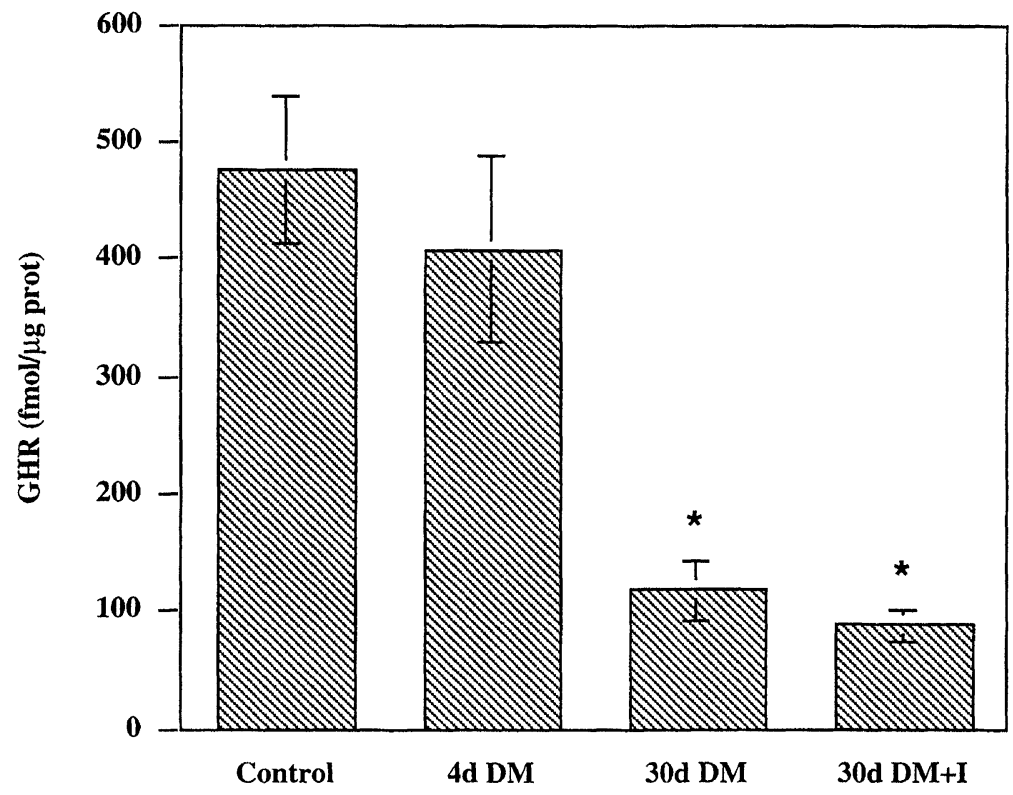

FIGURE 4 Binding capacity of GH receptor sites in liver of NOD non-diabetic (control), in 4 days and 30 days diabetic (DM) NOD mice and in 30 day diabetic animals treated with $4 \mathrm{IU}$ of ultralente insulin (DM+I). $n=6$ in each group. ${ }^{*} p<0.0001$. 
in serum GH levels in NOD diabetic mice. This is in contrary to previous reports on the usual model of animal IDDM, i.e., streptozotocin injection. In this model decreased circulating GH levels have been described, probably due to inhibition of GH release from the pituitary (Tannenbaum, 1981).

Increased GH action on target tissues may be an important risk factor (independent of IGF-I) for the development of diabetic complications, such as nephropathy and retinopathy. Whereas transgenic mice for bovine-GH develop advanced glomerulosclerosis and die of renal failure, transgenic mice for a variant of $\mathrm{GH}$ which antagonizes native $\mathrm{GH}$ effects (and causes decreased somatic growth) are protected against the development of nephropathy (Esposito et al., 1996). Recently Doublier et al. (1997) provided an additional evidence for the importance of a high GH-low IGF-I environment for the development of glomerulosclerosis: transgenic mice for IGFBP-1 that display such a hormonal combination develop glomerulosclerosis. Doi et al. (1990) have shown the natural history of long-standing diabetes in NOD mice. In these animals serum creatinine levels remain normal even after 3 months of diabetes. However, they develop progressive albuminuria and glomerular changes (such as mesangial expansion and sclerosis) that are more similar to diabetic glomerulosclerosis. In the present study we show that renal GHR mRNA decreases only after 3 weeks of diabetes, whereas GHBP mRNA levels remain unchanged. On the other hand, liver GHR and GHBP mRNA are profoundly decreased early after diabetes onset. GHRs are upregulated in diabetic adipocytes, causing an enhanced sensitivity to GH (Solomon et al., 1990). Thus, GHR and GHBP may be differentially regulated in IDDM.

Renal GH binding to kidney tissue is increased in diabetic rats (Marshall et al., 1991). In addition, renal GHBP is upregulated in a model of long-term diabetes (Landau et al., 1998). No change in renal GHR mRNA levels was seen in that model. Kidney IGF-I protein is accumulated in diabetic animals (Segev et al., 1997) together with an increase in kidney IGFBP-1. Given the increased circulating $\mathrm{GH}$ levels seen in this model as well as in human disease, an increased biological effect of $\mathrm{GH}$ on the kidney tissue (including sclerosis) is possible. However, this hypothesis will have to be further investigated in future studies.

Stunted growth in children with IDDM is a known clinical observation, even though increased GH levels are known in human disease. Since most of the growth promoting actions of $\mathrm{GH}$ are mediated by (predominantly liver originated) IGF-I action on bone, a GH insensitivity would be a possible explanation. Such insensitivity to $\mathrm{GH}$ could take place at the receptor levels (Bornfelt et al., 1989) or in postreceptor mechanisms (Maes et al., 1986). We show in this study that circulating IGF-I levels are decreased in diabetic mice. In a previous study (Segev et al., 1997) we have shown that this decrease in serum IGF-I is associated with complex changes in the IGFBPs: IGFBP-3 (the predominant carrier of IGF in the circulation) and IGFBP-4 decreased whereas IGFBP-1 increased. Analysis of $\mathrm{GH}$ binding to liver membranes also showed a decreased receptor binding capacity, with no change in affinity. Previous studies have shown a decrease in liver GHBP in diabetic states. Plasma concentrations of GHBP are reduced in untreated spontaneously diabetic BB rats, with full normalization during insulin administration (Massa et al., 1993). A decrease in serum GHBP was found in human patients with IDDM (Mercado et al., 1992). Such reduced IGF-I secretion is associated with low hepatic GHR levels that also normalize during insulin treatment (Postel Vinay et al., 1982).

A similar relationship between serum insulin levels and serum GHBP was also shown in humans (Kratzsch et al., 1996). We show here that elevated serum GH and decreased serum IGF-I levels are associated with a decreased 
expression of liver GHR and GHBP mRNA and $\mathrm{GH}$ binding. Insulin treatment did not fully reverse these findings. Previous studies in rats have raised the possibility of a cross binding of hGH with the rat prolactin receptor (Postel Vinay and Desbuquois, 1977). No data is available on hGH binding to prolactin receptor in mice. In addition, our mRNA results support our hypothesis that there is really a decrease in GHR message in IDDM. Even though a significant reduction in serum glucose was achieved in our insulin-treated diabetic animals, no tight control of the hyperglycemic state was reached. Thus, it is possible that a much tighter control of hyperglycemia would cause a reversal of the changes in serum IGF-I and liver GHR expression.

In summary, increased serum GH levels are documented in NOD diabetic mice 4 weeks after the appearance of glycosuria, similarly to the changes described in humans. The decrease in liver GHR levels and decreased serum IGF-I suggest a state of $\mathrm{GH}$ resistance at this organ level. This increase in circulating $\mathrm{GH}$ may affect target organs for diabetic complications, such as the kidney. Further studies are needed in order to ascertain whether normalizing increased GH levels can modulate those changes.

\section{Acknowledgments}

This study was supported by the Sarah Lea and Jesse Z. Shafer Trust.

\section{References}

Bach, L. A. and Jerums, G. (1990) Effect of puberty on initial kidney growth and rise in kidney IGF-I in diabetic rats. Diabetes, 39, 557-562.

Bergeron, J. J. M., Posner, B. I., Josefsberg, Z. and Sikstrom, R. (1978) Intracellular polypeptide hormone receptors. The demonstration for specific binding sites for insulin and human growth hormone in Golgi fractions isolated from the liver of female rats. J. Biol. Chem., 253, 4058-4066.

Blankestijn, P. J., Derkx, F. H., Birkenhager, J. C., Lamberts, S. W., Mulder, P., Verschoor, L., Schalekamp, M. A. and Weber, R. F. (1993) Glomerular hyperfiltration in insulin dependent diabetes mellitus is correlated with enhanced growth hormone secretion. J. Clin. Endocrinol. Metab., 77, 498-502.

Borch-Johnsen, K., Andersen, P. K. and Deckert, T. (1985) The effect of proteinuria on relative mortality of type 1 (insulin dependent) diabetes mellitus. Diabetologia, 28, 590-596.

Bornfelt, K. E., Arnqvist, H. J., Enberg, B., Mathews, L. S. and Norstedt, G. (1989) Regulation of IGF-I and growth hormone receptor gene expression by diabetes and nutritional state in rat tissues. J. Endocrinol., 122, 651-656.

Chieco, P., Venturini, A. P., Barbanti, M. and Romagnoli, E. A. (1993) A quantitative cytochemical study on the pathogenesis of streptozotocin-induced epithelial tumors in rat kidney. Toxicol. Pathol., 21, 402-408.

Chin, E., Zhou, J. and Bondy, C. (1992) Renal growth hormone gene expression: relationship to renal insulinlike growth factor system. Endocrinology, 131, 3061-3066.

Cunningham, B. C., Ultsch, M., De Vos, A. M., Mulkerrin, M. G., Clauser, K. R. and Wells, J. A. (1991) Dimerization of the extracellular domain of the human growth hormone receptor by a single hormone molecule. Science, 254, $821-$ 825.

Deckert, T., Poulsen, J. E. and Larsen, M. (1978) Prognosis of diabetics with diabetes onset before age of thirty-one. Diabetologia, 14, 363-377.

Doi, T., Hattori, M., Agodoa, Y. C., Sato, T., Yoshida, H., Striker, L. and Striker, G. (1990) Gomerular lesions in nonobese diabetic mouse: Before and after the onset of hyperglycemia. Lab. Invest., 63, 204-212.

Doublier, S., Fouqueray, B., Seurin, D., Verpont, M. C., Gilbert, T., Striker, L. J., Striker, G. E., Binoux, M. and Baud, L. (1997) Overexpression of human insulin-like growth factor binding protein-1 in transgenic mice: a new model of glomerulosclerosis (Abstr). J. Am. Soc. Nephrol., 8, A2295.

English, D. E., Barnum, C. L., Russell, S. M. and Nicoll, C. S. (1993) Hypophysectomy partially restores the responsiveness of diabetic rats to growth hormone: further evidence of dissociation between growth responses and serum IGF-I concentration. Endocrine. J., 1, 73-78.

Eshet, R., Peleg, S., Josefsberg, Z., Fuchs, C., Arnon, R. and Laron, Z. (1985) Some properties of the plasma hGH activity in patients with Laron-type dwarfism determine by a radioreceptor assay using human liver tissue. Horm. Res., 22, 276-283.

Esposito, C., Liu, Z. H., Striker, G. E., Phillips, C., Chen, N. Y., Chen, W. Y., Kopchick, J. J. and Sriker, L. J. (1996) Inhibition of diabetic nephropathy by a GH antagonist: a molecular analysis. Kidney Int., 50, 506-514.

Flyvbjerg, A., Frystyk, J., Thorlacius-Ussing, O. and Ørskov, H. (1989) Somatostatin analogue administration prevents increase in kidney somatomedin $\mathrm{C}$ and initial renal growth in diabetic and uninephrectomized rats. Diabetologia, 32, $261-265$.

Flyvbjerg, A., Kessler, U., Dorka, B., Funk, B., Ørskov, H. and Kiess, W. (1992) Transient increase in renal IGF binding proteins during initial kidney hypertrophy in experimental diabetes in rats. Diabetologia, 35, 589-593.

Gronowski, A. M. and Rotwein, P. (1994) Rapid changes in nuclear protein tyrosine phosphorylation after growth hormone treatment in vivo. J. Biol. Chem., 269, 7874-7878.

Hayford, J. T., Danney, M. M., Hendrix, J. A. and Thompson, R. G. (1980) Integrated concentration of growth hormone in juvenile-onset diabetes. Diabetes, 29, 391-398.

Holly, J. M. P., Amiel, S. A., Sandhu, R. R., Rees, L. H. and Wass, J. A. H. (1988) The role of growth hormone in diabetes mellitus. J. Endocrinol., 118, 353-364. 
Horton, L., Fox, C., Corrin, B. and Sönksen, P. H. (1977) Streptozotocin-induced renal tumors in rats. $\mathrm{Br}$. J. Cancer, 36, 692-699.

Houssay, B. A. (1936) The hypophysis and metabolism. N. Engl. J. Med., 214, 961-970.

Kratzsch, J., Kellner, K., Zilkens, T., Scmidt-Gayk, H., Selisko, T. and Scholz, G. H. (1996) Growth hormone binding protein related immunoreactivity is regulated by the degree of insulinopenia in diabetes mellitus. Clin. Endocrinol., 44, 673-678.

Landau, D., Domene', H., Flyvbjerg, A., Grönbaek, H., Roberts, C. T. Jr., Argov, S. and LeRoith, D. (1998) Differential expression of renal growth hormone receptor and its binding protein in experimental diabetes mellitus. Growth Hormone and IGF Research, 8, 39-45.

Lowry, O. H., Rosebrough, N. J., Farr, A. L. and Randall, R. J. (1951) Protein measurement with the Folin phenol reagent. J. Biol. Chem., 74, 265-275.

Maes, M., Underwood, L. E. and Ketelslegers, J. M. (1986) Low serum somatomedin $C$ in insulin dependent diabetes: Evidence for a postreceptor mechanism. Endocrinology, 118, $377-382$.

Marshall, S. M., Flyvbjerg, A., Frystyk, J., Korsgaard, L. and Ørskov, H. (1991) Renal insulin-like growth factor I and GHR binding in experimental diabetes and after unilateral nephrectomy in the rat. Diabetologia, 34, 632-639.

Massa, G., Verhaeghe, J., Vanderschueren-Lodeweyckx, M. and Bouillon, R. (1993) Normalization of decreased plasma concentrations of growth hormone binding protein by insulin treatment in spontaneously diabetic BB rats. Horm. Metabol. Res., 25, 325-326.

Mercado, M., Molitch, M. E. and Bauman, G. (1992) Low plasma growth hormone binding protein in IDDM. Diabetes, 41, 605-609.

Murata, A., Yasuda, T. and Niimi, H. (1994) Two cases of insulin-dependent diabetes mellitus under insulin treatment with slow height velocity: relationship of growth hormone-binding protein, metabolic control and growth. Acta. Paediatr. Jpn., 36, 272-275.

Phillip, M., Werner, H., Palese, T., Kowarski, A. A. and Stene, M. (1994) Differential accumulation of insulinlike growth factor-I in kidneys of pre- and postpubertal streptozotocin-diabetic rats. J. Mol. Endocrinol., 12, $215-224$.
Phillips, L. S. and Orawski, A. J. (1977) Nutrition and Somatomedin. III. Diabetic control, somatomedin and growth in rats. Diabetes, 26, 864-869.

Postel-Vinay, M. C. and Desbuquois, B. (1977) Interaction of human growth hormone with isolated rat liver cells. Endocrinology, 100, 209-215.

Postel Vinay, M. C., Cohen-Tanugi, E. and Charrier, J. (1982) Growth hormone receptors in rat liver membranes: effect of refeeding and correlation with plasma somatomedin activity. Mol. Cell Endocrinol., 28, 667-670.

Press, M., Tamborlane, W. V. and Sherwin, R. S. (1984) Importance of raised growth hormone levels in mediating the metabolic derangement of diabetes. New Engl. J. Med., 310, 810-815.

Segev, Y., Landau, D., Marbach, M., Schadeh, N., Flyvbjerg, A. and Phillip, M. (1997) Renal hypertrophy in hyperglycemic nonobese diabetic mice is associated with persistent renal accumulation of insulin-like growth factor (IGF)-I. J. Am. Soc. Nephrol., 8, 436-444.

Solomon, S. S., Sibley, S. D. and Cunningham, T. M. (1990) Growth hormone receptors are up-regulated in diabetic adipocytes. Endocrinology, 127, 1544-1546.

Takahashi, K., Daughaday, W. H. and Kipnis, D. M. (1971) Regulation of immunoreactive growth hormone secretion in male rats. Endocrinology, 88, 909-917.

Tannenbaum, G. H. (1981) Growth hormone secretory dynamics in streptozotocin diabetes: evidence of a role for endogenous circulating somatostatin. Endocrinology, 108, $76-82$.

Tochino, Y. (1984) Breeding and characteristics of a spontaneously diabetic nonobese strain (NOD mouse) of mice. In: Shafrir, E. and Renold, A. E. (Eds.), Lessons from Animal Diabetes (London: John Libbey), pp. 93-100.

Tushina, T. and Friesen, H. G. (1973) Radioreceptor assay for growth hormone. J. Clin. Endocrinol. Metab., 37, 334-337.

Velasquez, M. T., Kimmel, P. L. and Michaelis, O. E. (1990) Animal models of spontaneous diabetic kidney disease. FASEB I., 4, 2850-2859.

Werner, H., Shen Orr, Z., Stannard, B., Burguera, B., Roberts, C. T. Jr., and LeRoith, D. (1990) Experimental diabetes increases insulin-like growth factor-I and II receptor concentration in kidney. Diabetes, 39, 1490-1497.

Wicker, L., Miller, B. J. and Mullen, Y. (1986) Transfer of autoimmune diabetes mellitus with splenocytes from the non-obese diabetic (NOD) mice. Diabetes, 35, 855-860. 


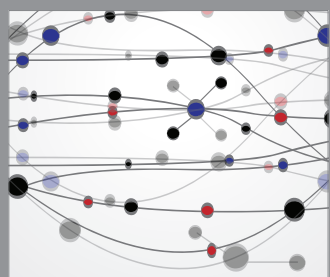

The Scientific World Journal
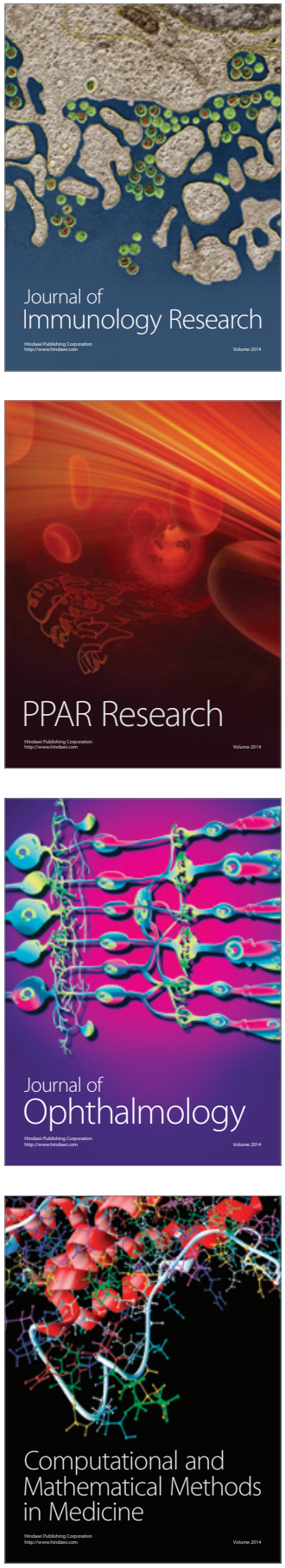

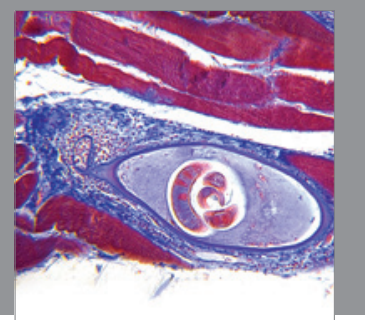

Gastroenterology

Research and Practice
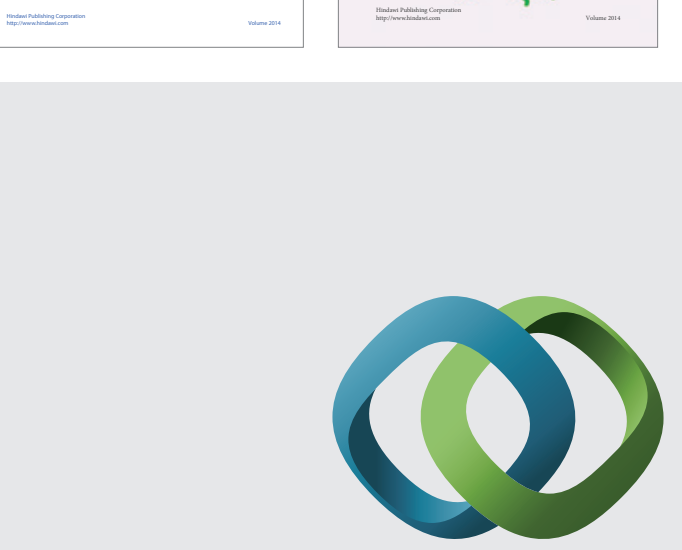

\section{Hindawi}

Submit your manuscripts at

http://www.hindawi.com
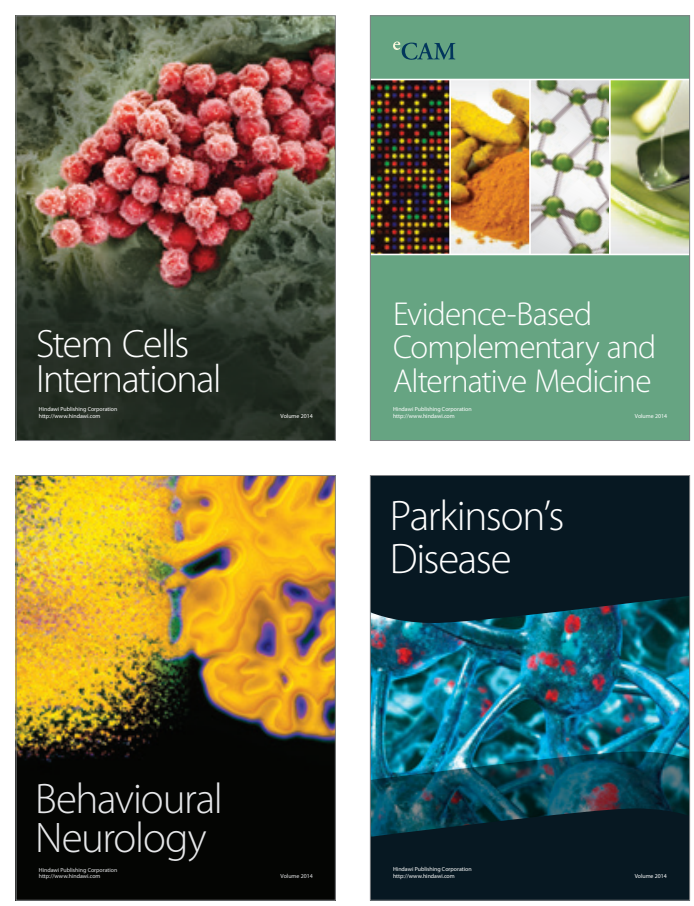

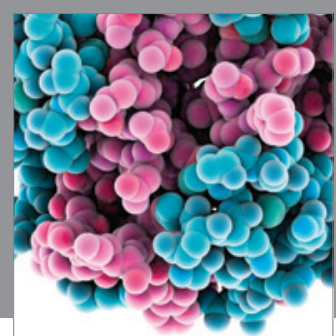

Journal of
Diabetes Research

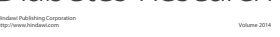

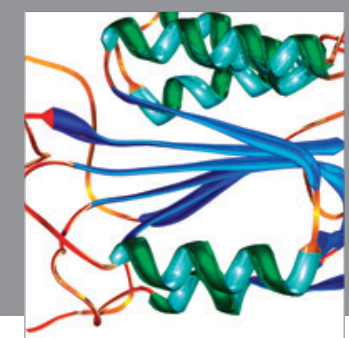

Disease Markers
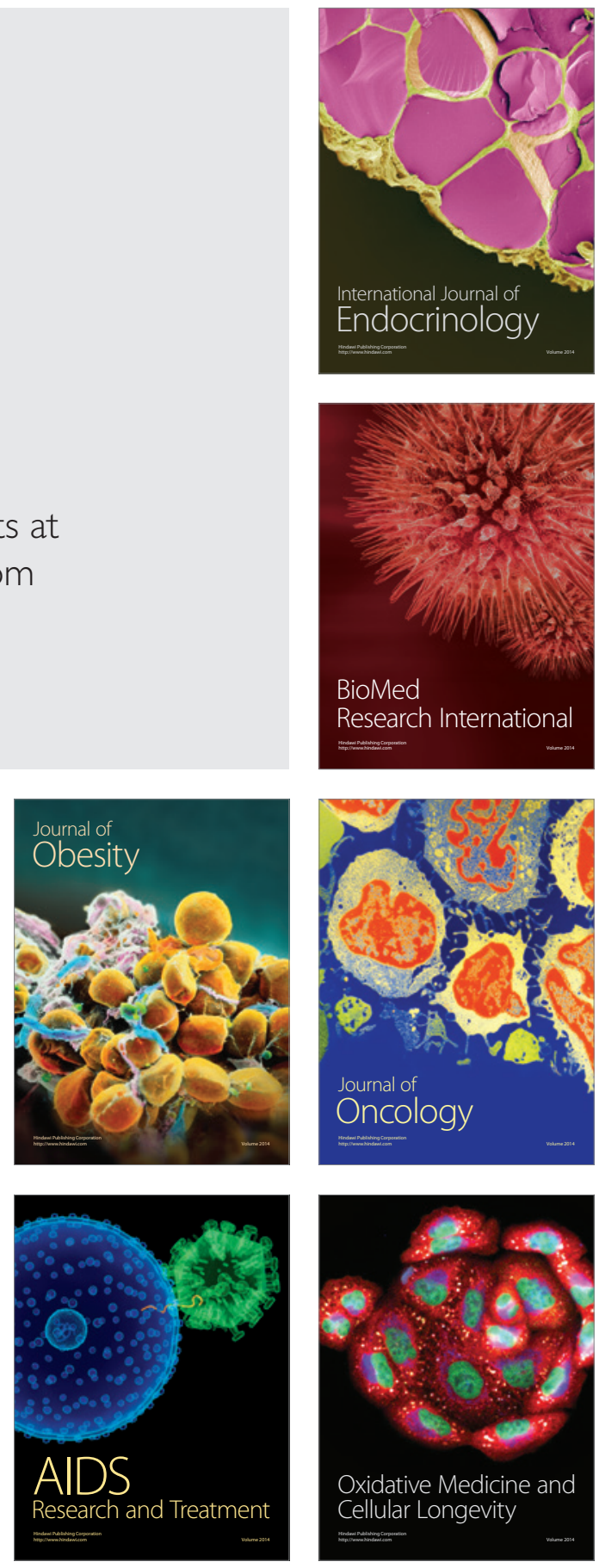